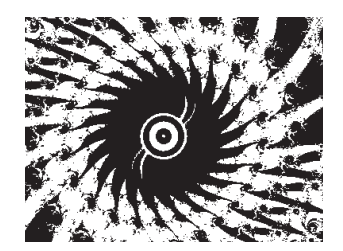

doi:10.5559/di.21.2.03

\title{
SUBJEKTIVNA DOBROBIT BRAČNIH PARTNERA PRILIKOM TRANZICIJE U RODITELJSTVO
}

Ina REIĆ ERCEGOVAC

Filozofski fakultet, Split

Zviezdan PENEZIĆ

Sveučilište u Zadru, Zadar

UDK: 159.947.5-055.52(497.5)

Izvorni znanstveni rad

Primlieno: 12. 11. 2010.

Roditelistvo je jedno od najvažniijh iskustava pojedinca koje donosi promjene u svim segmentima života. Većina istraživača i praktičara na području roditelistva i bliskih odnosa slaže se kako se tranzicija u roditeljstvo odražava na cjelokupno funkcioniranje pojedinca koji postaje roditeli. Cili ovog istraživanja bio je ispitati dolazi li do promiena u subjektivnoj dobrobiti bračnih partnera prilikom tranzicije u roditelistvo te pridonose li pozitivne osobine ličnosti, zadovolistvo brakom tijekom trudnoće, zadovolistvo roditelistvom i roditeliska kompetentnost većoj subjektivnoj dobrobiti novih roditelja. $U$ istraživanju je sudjelovalo 40 bračnih parova $(\mathrm{N}=80)$, koji su ispitani u dvije vremenske točke, tijekom drugog trimestra trudnoće te oko devet mjeseci postpartalno. Primijenjeni su sljedeći instrumenti: Upitnik općih podataka, Skala općeg zadovolistva životom, Skala zadovolistva brakom, Skala stresa, Skala roditeliske kompetentnosti te Upitnik za ispitivanje osobina ličnosti. Rezultati su pokazali da rođenje dieteta ne narušava zadovolistvo brakom, no pridonosi povećanju zadovolistva životom bračnih partnera, što je objašnjeno u kontekstu psihološke dobiti od roditelistva, generativnosti te revidirane hijerarhije ljudskih potreba. Zadovoljstvu životom prilikom tranziciije u roditelistvo pridonosi struktura ličnosti bračnih partnera, posebno osobine ekstraverzije i savjesnosti, dok je najbolii prediktor zadovolistva brakom devet mieseci nakon porođaja, zadovolistvo brakom tijekom trudnoće te zadovolistvo roditeljstvom kao afektivna komponenta doživljaja roditelistva.

Ključne riječi: tranzicija u roditeljstvo, zadovoljistvo životom, zadovoljstvo brakom, roditeljska kompetentnost, osobine ličnosti 
Tranzicija u roditeljstvo, shvaćena kao reorganizacija života i unutarnjega svijeta pojedinca koji postaje roditelj, obuhvaća razdoblje od trudnoće do nekoliko mjeseci nakon porođaja. Ipak, u literaturi se može pronaći različito vremensko definiranje ove tranzicije, jer ona nije definirana samim rođenjem prvoga djeteta, već upravo cjelokupnim promjenama koje se događaju dolaskom djeteta $u$ obiteljski život. Tranzicija $u$ roditeljstvo proučava se u okviru brojnih teorijskih koncepata obitelji i roditeljstva. U kontekstu simboličko-interakcijske teorije (Lemme, 1995.; Ward, 2004.), u kojoj središnje mjesto imaju uloge koje pojedinci odabiru i prema njima se ponašaju, poseban je naglasak na promjenama u zastupljenosti različitih uloga prelaskom u roditeljstvo, odnosno činjenici da uloge bračnih drugova i ljubavnih partnera uzmiču pred ulogama roditelja, koje s vremenom zauzimaju sve više mjesta $u$ definiranju nečijeg identiteta. Istraživanja su pokazala da je prilikom tranzicije $\mathrm{u}$ roditeljstvo prisutna tradicionalna podjela uloga (Kalicki i sur., 1998.; Lemme, 1995.) te da se jedan ili oba partnera mogu osjećati zarobljeno u spoznaji da je roditeljstvo uloga koja će trajati zauvijek, pa iz toga mogu proizaći negativni efekti tranzicije $u$ roditeljstvo na subjektivnu dobrobit bračnih partnera. Iz teorije sukoba (Belsky i Pensky, 1988.; Olsen i sur., 2006.; Wadsby i Sydsjo, 2001.; Willen, 1996.) proizlazi feministički model objašnjenja neravnopravnosti među spolovima, $\mathrm{u}$ okviru kojega tradicionalna podjela uloga $\mathrm{u}$ obitelji predstavlja poteškoće prilikom tranzicije u roditeljstvo, zbog često neravnomjerne raspodjele obveza i velikih odricanja, koja su češća kod žena. U kontekstu ovoga pristupa, tranzicija u roditeljstvo mogla bi se negativnije odraziti na subjektivnu dobrobit žena, no istraživanja ne potvrđuju uvijek ovu pretpostavku. Naime, neka su istraživanja pokazala da muškarci doživljavaju negativnije promjene $\mathrm{u}$ dobrobiti nego žene (Wadsby i Sydsjo, 2001.; Willen, 1996.), dok neka druga istraživanja sugeriraju da se tranzicija $u$ roditeljstvo negativno odražava prije svega na majke (Belsky i Pensky, 1988.; Olsen i sur., 2006.).

U okviru sustavnoga pristupa obitelji, koji se temelji na ekološkom shvaćanju ljudskoga razvoja (Bronfenbrenner, 1979.), obitelj je definirana kao sustav međuovisnih članova. Poteškoće koje se javljaju dolaskom djeteta u obitelj uglavnom su rezultat sukoba partnerskih i roditeljskih podsustava. Podsustavi obitelji hijerarhijski su organizirani i u međusobnoj su interakciji, pa stoga posebnosti svakoga člana podsustava utječu na funkcioniranje cijeloga sustava, odnosno cijele obitelji. Pri tome se obitelji razlikuju po prilagodljivosti, pa su neki obiteljski sustavi prilagodljiviji od drugih, no većina prolazi manje ili veće poteškoće prilikom raznih tranzicija. 
DRUŠ. ISTRAŽ. ZAGREB GOD. 21 (2012), BR. $2(116)$

STR. $341-361$

REIĆ ERCEGOVAC, I., PENEZIĆ, Z.:

SUBJEKTIVNA
Starija istraživanja tranzicije u roditeljstvo nerijetko su bila opterećena metodološkim nedostacima jer su se uglavnom rabile kliničke metode (Benedek, 1959., prema Demick, 2002.) ili retrospektivni intervjui (Feeney i sur., 2001.). Rane kliničke studije o roditeljstvu rađene su u okviru psihoanalitičkoga pristupa na specifičnim uzorcima, koji nisu bili reprezentativni za populaciju novih roditelja. Istraživanja u kojima su upotrijebljeni retrospektivni intervjui također su imala određenih nedostataka, ponajprije zato što su se propitkivala iskustva roditelja o rođenju prvoga djeteta s odmakom od nekoliko godina, što dovodi u pitanje valjanost rezultata. U zadnjim desetljećima istraživanja su sve češće longitudinalnoga karaktera, pa se promjene koje donosi prvo roditeljstvo ispituju tako da se sudionici prate od perioda kada nemaju djecu nadalje. Takva istraživanja pokazuju da prilikom tranzicije u roditeljstvo kod roditelja dolazi do povećanja anksioznosti i depresivnosti te opadanja subjektivne dobrobiti (Feeney i sur., 2001.), što je važno, jer je uspješna tranzicija dobra podloga za kvalitetno roditeljstvo i kvalitetu ranih interakcija roditelja i djece.

Brojnim suvremenim istraživanjima pokušalo se utvrditi čimbenike koji bi pridonijeli što uspješnijoj tranziciji u roditeljstvo, no rezultati istraživanja nisu jednoznačni. Neki od čimbenika za koje je utvrđeno da pridonose uspješnoj tranziciji jesu tradicionalna podjela bračnih uloga, percipirana ravnopravnost raspodjele poslova te visoko zadovoljstvo obiteljskim životom (Ward, 2004.). Matthey i sur. (2003.) navode da su razne varijable povezane $\mathrm{s}$ uspješnom prilagodbom na roditeljstvo u različitim vremenskim točkama tranzicije. Naime, rezultati njihova longitudinalnog istraživanja na 157 parova koji su očekivali rođenje prvoga djeteta pokazali su da je rana prilagodba na roditeljstvo (šest tjedana postpartalno) bila povezana s kvalitetom odnosa obaju partnera s vlastitim roditeljima (kod žena samo s majkom), kao i nekim osobinama ličnosti (neuroticizam). Za kasniju je pak prilagodbu (godinu dana nakon rođenja djeteta) najbolji prediktor bila kvaliteta odnosa među partnerima. Longitudinalno istraživanje na više od tri stotine parova koji su iščekivali rođenje prvoga djeteta (Morse i sur., 2000.) pokazalo je značajan psihološki stres kod 12\% budućih očeva i 30\% budućih majki tijekom trudnoće, pri čemu su se mlađa dob, negativno raspoloženje, snižena kvaliteta partnerskog odnosa i niska socijalna potpora pokazali glavnim prediktorima stresa u trudnoći. S druge strane, negativno vlastito raspoloženje i raspoloženje partnera, kao i loša kvaliteta partnerskog odnosa sredinom trudnoće, pokazali su se prediktivnima za postpartalni stres.

Gjerdingen i Center (2003.) utvrdili su u longitudinalnom istraživanju na uzorku od 261 sudionika obaju spolova da šest 
DRUŠ. ISTRAŽ. ZAGREB GOD. 21 (2012)

BR. $2(116)$

STR. 341-361

REIĆ ERCEGOVAC, I. PENEZIĆ, Z:

SUBJEKTIVNA.. mjeseci postpartalno opada kvaliteta života u odnosu na onu tijekom trudnoće, posebno kod muškaraca. Naime, muškarci su izvještavali o više zdravstvenih problema i općenito pogoršanom zdravstvenom statusu, dok je kod žena najistaknutija poteškoća bila manjak sna. Pregledom dostupne literature od 1992. do 2002. godine, Ohrling i Nystrom (2004.) identificirale su nekoliko kategorija roditeljskih aktivnosti koje najviše zaokupljaju nove majke i očeve u prvoj godini djetetova života. Čini se da tranzicija u roditeljstvo za majke u prvi plan dovodi pitanje vlastite odgovornosti u majčinskoj ulozi i osobnoga zadovoljstva koje majčinstvo pruža. Jednako je prisutan stres, upravo zbog velike odgovornosti, umora i manjka vremena za sebe. Očevima pak tranzicija znači izazov njihovoj ulozi i kao partnera i kao roditelja, ali i donosi napetost zbog povećane odgovornosti - $\mathrm{i}$ u brizi za dijete i u tradicionalnijim pitanjima, poput ostvarivanja dovoljno materijalnih sredstava za uzdržavanje povećane obitelji.

Budući da je tranzicija u roditeljstvo važan temelj za kasnije kvalitetno roditeljstvo, subjektivna dobrobit roditelja tijekom te važne životne tranzicije od velike je važnosti i za njih i za razvoj djeteta. Neupitno je da postoje brojni čimbenici koji određuju uspješnost prilagodbe na roditeljstvo i kvalitetu najranijih interakcija s djetetom. $U$ tom kontekstu može se istraživati i doživljaj roditeljstva, što ga većina autora definira dvjema osnovnim komponentama - zadovoljstvom i kompetentnošću, iako s određenim terminološkim razlikama. Zadovoljstvo roditeljstvom kao afektivna komponenta doživljaja roditeljstva odnosi se na subjektivnu roditeljsku procjenu odnosa prema vlastitu roditeljstvu i roditeljskoj ulozi (Sabatelli i Waldron, 1995.). Roditeljska kompetentnost (ili samoefikasnost) subjektivna je procjena vlastite uspješnosti $u$ ispunjavanju društveno zadanih normi roditeljstva, odnosno procjena roditelja o tome koliko je sposoban i uspješan kao roditelj. Samoprocjena roditeljske kompetentnosti posebno je ugrožena $\mathrm{u}$ vremenu tranzicije $\mathrm{u}$ roditeljstvo, odnosno prvoj godini nakon porođaja, zbog preuzimanja nove uloge, njezine složenosti i zahtjevnosti te drugih čimbenika iz socijalnog okruženja (Ljubetić, 2007.). Važnost pozitivnoga doživljaja roditeljstva ogleda se u činjenici da se roditelji koji sebe percipiraju kompetentnima osjećaju spremnima i odgovornima za roditeljsku ulogu i obavljanje roditeljskih dužnosti, ali i uživaju u roditeljstvu, pa su spremni osigurati poticajno okruženje za razvoj djeteta (Lacković-Grgin, 1994.). Stoga se može pretpostaviti da subjektivni doživljaj roditeljstva može moderirati odnos između stresa novog roditeljstva i subjektivne dobrobiti bračnih partnera te njihove kvalitete života.

Općenito se može reći da su dosadašnja istraživanja prilagodbe na prvo roditeljstvo najčešće bila usmjerena na prou- 
DRUŠ. ISTRAŽ. ZAGREB GOD. 21 (2012), BR. $2(116)$

STR. $341-361$

REIĆ ERCEGOVAC, I., PENEZIĆ, Z.:

SUBJEKTIVNA.. čavanje promjena u oblicima kvalitete partnerskih odnosa, koje su neposredna ili posredna posljedica tranzicije $u$ roditeljstvo. Velik broj istraživanja upozorio je na negativan efekt tranzicije u roditeljstvo na kvalitetu partnerskih odnosa, posebno u istraživanjima u kojima je kvaliteta odnosa bila predstavljana kao bračno zadovoljstvo (Cast, 2004.; Cox i sur., 1999.; De Judicibus i McCabe, 2002.; Doss i sur., 2009.; Elek i sur., 2003.; Helms-Erikson, 2001.; Knauth, 2000.; Lawrence i sur., 2008.). Pregledom dostupne relevantne literature može se zaključiti kako su objašnjenja toga negativnog efekta tranzicije u roditeljstvo na zadovoljstvo brakom višestruka, a pokrivaju cijeli dijapazon mogućih čimbenika - od manjka vremena za posvećivanje partnerskom odnosu, velike preopterećenosti partnera (posebno majke) novom, roditeljskom ulogom, preko povećane anksioznosti i povišene razine stresa novih roditelja (Feeney i sur., 2001.; Fennie, 2001.; McConachie i sur., 2008.; Olsen i sur., 2006.; Ross i McLean, 2006.), manjka sna i narušena ritma spavanja (Medina i sur., 2009.), promjena u ženskoj seksualnosti (Ahlborg, 2004.; Barrett i sur., 2000.; Von Sydow, 1999.) do učestalijih konflikata oko raspodjele kućanskih i drugih obveza (Kalicki i sur., 1998.; Lemme, 1995.) te nesuglasica vezanih uz roditeljska pitanja. $\mathrm{S}$ druge strane, rijetkim se istraživanjima ispitivao utjecaj tranzicije u roditeljstvo na zadovoljstvo životom pojedinaca koji postaju roditelji, a malobrojna istraživanja odnosa tih varijabli ne upućuju na njihov jednoznačni odnos (DeFrain i Olson, 1999.; Di Tella i sur., 2003.; Obradović i Čudina-Obradović, 2001.; Schoon i sur., 2005.; Wilkinson, 1995.). Budući da neki autori govore o temporalnoj nestabilnosti zadovoljstva životom (Diener i sur., 2006.; Veenhoven, 1995.) zbog činjenice da pojedinci evaluiraju svoj život periodično te se procjene zadovoljstva životom mijenjaju s obzirom na životne okolnosti, opravdanim se čini pretpostaviti da će tranzicija u roditeljstvo, kao jedna od najvažnijih životnih promjena, utjecati na procjene zadovoljstva životom, pa je jedan od ciljeva ovog istraživanja provjeriti navedenu pretpostavku.

\section{CILJ I PROBLEMI ISTRAŽIVANJA}

Cilj ovog istraživanja bio je ispitati subjektivnu dobrobit partnera prilikom tranzicije u roditeljstvo te utvrditi koji čimbenici pridonose uspješnijoj prilagodbi na najvažniju životnu ulo$\mathrm{gu}$ - ulogu roditelja.

Tranzicija u roditeljstvo, s obzirom na brojne promjene koje donosi, može biti stresan period te rezultirati poteškoćama u prilagodbi i psihičkom funkcioniranju bračnih partnera. Dijete može povećati već postojeće razlike kod roditelja/partnera te smanjiti zadovoljstvo koje im je ranije pružao njihov odnos. Moguće je da se parovi prilagođavaju životu nakon 
DRUŠ. ISTRAŽ. ZAGREB GOD. 21 (2012) BR. 2 (116),

STR. 341-361

REIĆ ERCEGOVAC, I. PENEZIĆ, Z: SUBJEKTIVNA..

\section{METODA}

\section{Sudionici}

rođenja djeteta na isti način kao što su to činili i ranije, pa je vjerojatnost izranjanja starih problema veća. Tranzicija u roditeljstvo jest izazov zadovoljstvu koje su partneri imali u svojoj vezi. S obzirom na navedeno, valja očekivati da dolazak djeteta u obitelj donosi promjene u subjektivnoj dobrobiti roditelja (zadovoljstvu životom i zadovoljstvu brakom).

Budući da su osobine ličnosti dobar prediktor zadovoljstva životom, a da ispitivanja efekata zadovoljstva različitim životnim domenama na globalni osjećaj zadovoljstva životom pokazuju da je zadovoljstvo brakom najznačajnije povezano s općim zadovoljstvom (Diener i sur., 2004.), može se pretpostaviti da će određene osobine ličnosti (ugodnost, savjesnost i otvorenost za nova iskustva) pridonijeti i većem zadovoljstvu brakom i roditeljstvom, a time i ukupnoj subjektivnoj dobrobiti roditelja. Oslanjajući se na sustavni pristup obitelji i modele roditeljstva koji predviđaju međusobnu povezanost funkcioniranja roditeljskih i bračnih odnosa, valja pretpostaviti da će pozitivan doživljaj roditeljstva (visoko zadovoljstvo roditeljstvom i procjena visoke roditeljske kompetentnosti) također pridonijeti većem bračnom i životnom zadovoljstvu partnera.

Kako bi se ostvario navedeni cilj, ovim se istraživanjem pokušalo odgovoriti na dva osnovna problema:

1. Ispitati dolazi li do promjena u subjektivnoj dobrobiti bračnih partnera prilikom tranzicije u roditeljstvo.

2. Utvrditi kakav je doprinos osobina ličnosti, zadovoljstva brakom tijekom trudnoće te doživljaja roditeljstva subjektivnoj dobrobiti bračnih partnera devet mjeseci nakon porođaja.

U istraživanju je sudjelovalo 40 bračnih parova $(\mathrm{N}=80)$ koji su očekivali rođenje prvoga djeteta. Svi su sudionici bili u bračnoj zajednici, koja je u prosjeku trajala 2,1 godine, s rasponom od 1 do 7 godina. Istraživanje je uključilo podjednak broj sudionika koji su imali srednju, odnosno višu ili visoku, stručnu spremu (32 ispitanika sa SSS i 48 sa VŠS/VSS). S obzirom na radni status, svi su muškarci bili zaposleni, a od žena je bilo zaposleno njih $75 \%$. Prosječna dob muškaraca bila je $M=29,48$ $(\mathrm{sd}=3,80)$, a raspon od 21 do 40 godina, dok je za žene prosječna dob $\mathrm{M}=27,00(\mathrm{sd}=3,69)$, s rasponom od 19 do 38 godina. U usporedbi s državnim prosjekom (Državni zavod za statistiku, 2009.), prosječna dob žena i muškaraca iz uzorka ne razlikuje se značajno od prosječne dobi u kojoj muškarci i žene postaju prvi put roditelji (tžene $=0,51 ; \mathrm{p}>0,05$; tmuškarci $=-0,04$; p $>0,05)$ u Republici Hrvatskoj. 


\section{Instrumenti}

Skala općeg zadovoljstva životom (Penezić, 1996.) sastoji se od 20 čestica, pri čemu se 17 čestica odnosi na procjene globalnoga zadovoljstva životom, dok 3 čestice služe za procjenu situacijskoga zadovoljstva životom. Sudionici su odgovarali zaokruživanjem odgovarajućega broja na skali Likertova tipa sa pet stupnjeva, a ukupan rezultat oblikovan je kao linearna kombinacija procjena na svim česticama. Viši rezultat označavao je i više zadovoljstvo životom. Pouzdanost skale u oba je mjerenja bila visoka i iznosila je Cronbach-alpha $=0,92$.

Skala zadovoljstva brakom (The Marital Satisfaction Scale, Roach i sur., 1981.) sastoji se od 48 čestica, od kojih polovina odražava pozitivan stav prema vlastitu braku, a polovina negativan. Sudionici su odgovarali zaokruživanjem odgovarajućega broja na skali Likertova tipa sa pet stupnjeva, a ukupan rezultat se, nakon obrnutoga bodovanja negativnih čestica, formirao kao linearna kombinacija svih procjena. Roach i sur. (1981.) u inicijalnoj su primjeni utvrdili jednofaktorsku strukturu skale i vrlo visoku pouzdanost (Cronbach-alpha $=0,98$ ). $\mathrm{U}$ ovom istraživanju skala je prvi put primijenjena na hrvatskom jezi$\mathrm{ku}$, a njezina pouzdanost $\mathrm{u}$ prvom mjerenju iznosila je Cronbach-alpha $=0,95$, a u drugom mjerenju Cronbach-alpha $=0,96$.

Podskala stresa dio je Upitnika Depresionosti, anksioznosti i stre$s a$ (DAS, Lovibond i Lovibond, 1995.) koji je razvijen na nekliničkom uzorku adolescenata i odraslih ljudi. Sastoji se od 42 čestice, odnosno tri podskale - depresivnosti, anksioznosti i stresa, od kojih svaka ima 14 čestica. U ovom istraživanju upotrijebljena je podskala stresa koja obuhvaća pokazatelje kronične, nespecifične pobuđenosti, poteškoće opuštanja, uznemirenost, nestrpljenje i sl. Skala je u ovom istraživanju prvi put primijenjena na hrvatskom jeziku. Sudionici su odgovarali zaokruživanjem odgovarajućega broja na skali Likertova tipa sa četiri stupnja, a ukupan rezultat oblikovan je kao linearna kombinacija procjena svih čestica podskale. Pouzdanost je u prvom mjerenju iznosila Cronbach-alpha $=0,89$, a u drugom mjerenju Cronbach-alpha $=0,86$.

Skala roditeljske kompetentnosti (Parenting Sense of Competence Scale, Gibaud-Wallston, i Wandersman, 1978.). Originalna verzija skale konstruirana je kako bi se mjerila percepcija roditeljske kompetentnosti u odnosu s dojenčadi, pa su utvrdili dvofaktorsku strukturu koja je potvrđena i u idućim istraživanjima (Johnston i Mash, 1989.; Ohan i sur., 2000.). I u ovom istraživanju utvrđena je dvofaktorska struktura, pri čemu dva faktora ukupno objašnjavaju $47 \%$ varijance. Rezultati su formirani kao linearne kombinacije procjena na dvije podskale roditeljske kompetentnosti i zadovoljstva roditeljstvom. Skala ukupno sadrži 17 čestica, a sudionici odgovaraju zaokruživanjem odgovarajućega broja na skali Likertova tipa sa šest stup- 
DRUŠ. ISTRAŽ. ZAGREB GOD. 21 (2012)

BR. 2 (116),

STR. 341-361

REIĆ ERCEGOVAC, I. PENEZIĆ, Z:

SUBJEKTIVNA..

\section{Postupak}

njeva, pri čemu viši rezultati označavaju i veću roditeljsku kompetentnost, odnosno veće zadovoljstvo roditeljstvom. Skala je za potrebe ovog istraživanja prevedena na hrvatski jezik te su provjerena njezina metrijska obilježja. Pouzdanost dviju podskala bila je zadovoljavajuća - za podskalu kompetentnosti iznosila je Cronbach-alpha $=0,89$, a za podskalu zadovoljstva Cronbach-alpha $=0,75$.

Goldbergov (2001.) IPIP 50 (International Personality Item Pool) upitnik ličnosti sa 50 kratkih tvrdnji za opis ponašanja, sa po 10 tvrdnji namijenjenih mjerenju svakog od 5 velikih faktora (ekstraverzija, neuroticizam, ugodnost, savjesnost te otvorenost za nova iskustva). Sudionici su odgovarali zaokruživanjem odgovarajućega broja na skali Likertova tipa sa pet stupnjeva, a ukupni rezultati oblikovani su kao linearne kombinacije procjena po pojedinim podskalama, odnosno osobinama ličnosti. Koeficijenti pouzdanosti kretali su se od Cronbach-alpha $=0,68$ za podskalu otvorenosti novim iskustvima do Cronbach-alpha $=0,86$ za podskalu ekstraverzije.

Skupina od 40 bračnih parova praćena je od perioda trudnoće do kraja prve godine djetetova života. U tom razdoblju sudionici su popunili set upitnika u dvije vremenske točke: jednom $\mathrm{u}$ drugom trimestru trudnoće te $\mathrm{u}$ trenutku kada im je prvo dijete imalo oko 9 mjeseci (raspon od 8 do 11 mjeseci). $U$ prvom ispitivanju sudionici su ispunjavali Upitnik općih podataka, Skalu općega zadovoljstva životom, Skalu zadovoljstva brakom, Skalu stresa te Upitnik za ispitivanje osobina ličnosti. U drugom ispitivanju sudionici su ispunjavali Skalu općega zadovoljstva životom, Skalu zadovoljstva brakom, Skalu stresa, Upitnik percipirane socijalne podrške te Skalu roditeljske kompetentnosti.

S potencijalnim sudionicima istraživanja osobno je uspostavljen kontakt u suradnji s Klubom trudnica i roditelja Split te Kliničkim bolničkim centrom Split - Klinikom za ženske bolesti i porode, uz dopuštenje Etičkoga povjerenstva. Ukupno je kontaktirano 50 parova koji su inicijalno pristali ispuniti upitnik. Od sudionika koji su zamoljeni za sudjelovanje u istraživanju, pošto im je objašnjena svrha istraživanja i okvirni sadržaj upitnika i skala, dio njih nije pristao na sudjelovanje, dok je i dio sudionika koji su inicijalno pristali sudjelovati odustao prilikom ispitivanja. Neki od njih svojevoljno su odustali, a dio sudionika morao je biti izostavljen iz analize podataka jer nije udovoljavao kriterijima za sudjelovanje $\mathrm{u}$ istraživanju zbog okolnosti koje su se tijekom istraživanja promijenile. Naime, kriteriji za sudjelovanje $u$ istraživanju bili su da se radi o prvoj bračnoj/izvanbračnoj zajednici, da je trudnoća prva, uredna, bez indikacija za bilo kakve poteškoće te 
da je porod protekao uredno, bez komplikacija, kao i da daljnji razvoj djeteta protječe bez izraženijih poteškoća. Tako je od ukupnoga broja sudionika $\mathrm{u}$ daljnju obradbu podataka uvršteno njih 80, odnosno 40 parova koji su ispunjavali sve kriterije i valjano ispunili sve upitnike $\mathrm{u}$ obje vremenske točke.

\section{REZULTATI}

(1) TABLICA 1

Rezultati Kolmogorov- Smirnovljevih testova (d) za testiranje normalnosti distribucija te test-retest koeficijenti pouzdanosti ( $r$ )

Prije analiza kojima se pokušalo odgovoriti na postavljeni problem istraživanja, provjereno je odstupaju li distribucije rezultata od normalnih distribucija, kako bi se odabrali primjereni postupci za njihovu obradbu. Stoga su provedeni Kolmogorov-Smirnovljevi testovi u oba mjerenja, rezultati kojih su prikazani u Tablici 1, zajedno s test-retest koeficijentima pouzdanosti kao indikatorima stabilnosti primijenjenih mjera.

\begin{tabular}{lccc}
\hline Varijable & \multicolumn{2}{c}{ Kolmogorov-Smirnov $(\mathrm{d})$} & $\begin{array}{c}\text { Korelacija između } \\
\text { dva mjerenja (r) }\end{array}$ \\
\hline Zadovoljstvo životom & 0,05 & 0,07 & $0,54^{* *}$ \\
Zadovoljstvo brakom & 0,11 & 0,09 & $0,53^{* *}$ \\
Stres & 0,10 & 0,07 & $0,40^{* *}$ \\
Roditeljska kompetentnost & - & 0,09 & \\
Zadovoljstvo roditeljstvom & - & 0,08 & \\
\hline
\end{tabular}

${ }^{*} \mathrm{p}<0,05 ;{ }^{* *} \mathrm{p}<0,01$

Iz Tablice 1 vidi se da se ni jedna distribucija ne razlikuje značajno od normalne, pa su u obradbi rezultata primijenjeni odgovarajući parametrijski postupci. Mjere zadovoljstva životom i brakom te stresa pokazale su zadovoljavajuću stabilnost između dva mjerenja (Tablica 1). Ipak, treba napomenuti kako su dobiveni koeficijenti nutarnje konzistencije (Cronbach-alpha koeficijenti pouzdanosti prikazani za sve skale u Metodi) značajno veći od test-retest koeficijenata pouzdanosti, što upućuje na situacijsku osjetljivost upotrijebljenih mjera subjektivne dobrobiti. Naime, zadovoljstvo životom i brakom te razina stresa, iako pokazuju relativnu stabilnost tijekom vremena, ipak su pod utjecajem situacijskih činitelja, odnosno životnih okolnosti. Zadovoljstvo životom može se promatrati kao stabilna značajka ličnosti, čemu u prilog idu i konzistentne korelacije zadovoljstva životom i osobina ličnosti te dimenzija raspoloženja (DeNeve i Cooper, 1998.; Hills i Argyle, 2001.; Pavot i sur., 1990.), međutim, dobivene korelacije između dva mjerenja upućuju i na činjenicu da je zadovoljstvo pod utjecajem životnih okolnosti, o čemu govore i Veenhoven (1995.) i Diener i sur. (2006.).

U Tablici 2 prikazane su aritmetičke sredine i standardne devijacije za pokazatelje subjektivne dobrobiti u oba mjerenja te rezultati analiza varijanci s ponovljenim mjerenjima koje su provedene da bi se utvrdile eventualne promjene u subjektivnoj dobrobiti muškaraca i žena između dva mjerenja. 


\begin{tabular}{|c|c|c|c|c|}
\hline Zavisne varijable & Efekti & & $\mathrm{M}(\mathrm{sd})$ & $\mathrm{F}$ \\
\hline \multirow[t]{3}{*}{ Zadovoljstvo životom } & Spol & $\begin{array}{l}\mathrm{m} \\
\check{z}\end{array}$ & $\begin{array}{l}79,14(9,91) \\
79,80(9,32)\end{array}$ & 0,12 \\
\hline & $\mathrm{t} 1 \mathrm{i} \mathrm{t} 2$ & $\begin{array}{l}\mathrm{t} 1 \\
\mathrm{t} 2\end{array}$ & $\begin{array}{l}78,29(9,99) \\
80,65(9,10)\end{array}$ & $5,28^{*}$ \\
\hline & Interakcija & $\begin{array}{l}\mathrm{m}, \mathrm{t} 1 \\
\check{\mathrm{z}}, \mathrm{t} 1 \\
\mathrm{~m}, \mathrm{t} 2 \\
\check{z}, \mathrm{t} 2\end{array}$ & $\begin{array}{l}77,97(9,93) \\
78,60(10,16) \\
80,30(9,89) \\
81,00(8,36)\end{array}$ & 0,01 \\
\hline \multirow[t]{3}{*}{ Zadovoljstvo brakom } & Spol & $\begin{array}{l}\mathrm{m} \\
\check{\mathrm{z}}\end{array}$ & $\begin{array}{l}179,07(24,44) \\
174,93(26,02)\end{array}$ & 0,70 \\
\hline & $\mathrm{t} 1 \mathrm{i} \mathrm{t} 2$ & $\begin{array}{l}\mathrm{t} 1 \\
\mathrm{t} 2\end{array}$ & $\begin{array}{l}178,65(23,64) \\
175,36(26,81)\end{array}$ & 1,41 \\
\hline & Interakcija & $\begin{array}{l}\mathrm{m}, \mathrm{t} 1 \\
\check{z}, \mathrm{t} 1 \\
\mathrm{~m}, \mathrm{t} 2 \\
\check{\mathrm{z}}, \mathrm{t} 2\end{array}$ & $\begin{array}{l}181,57(20,74) \\
175,72(26,16) \\
176,57(27,70) \\
174,15(26,18)\end{array}$ & 0,38 \\
\hline \multirow[t]{3}{*}{ Stres } & Spol & $\begin{array}{l}\mathrm{m} \\
\check{z}\end{array}$ & $\begin{array}{l}12,59(7,59) \\
12,83(8,40)\end{array}$ & 0,03 \\
\hline & t1 i t2 & $\begin{array}{l}\mathrm{t} 1 \\
\mathrm{t} 2\end{array}$ & $\begin{array}{l}12,65(8,78) \\
12,78(7,15)\end{array}$ & 0,02 \\
\hline & Interakcija & $\begin{array}{l}\mathrm{m}, \mathrm{t} 1 \\
\check{\mathrm{z}}, \mathrm{t} 1 \\
\mathrm{~m}, \mathrm{t} 2 \\
\check{\mathrm{z}}, \mathrm{t} 2\end{array}$ & $\begin{array}{l}12,65(8,10) \\
12,64(9,52) \\
12,52(7,15) \\
13,02(7,22)\end{array}$ & 0,07 \\
\hline
\end{tabular}

$\mathrm{df}=1,78 ;{ }^{*} \mathrm{p}<0,05 ; \mathrm{t} 1$ - rezultati prvoga mjerenja (tijekom trudnoće); $\mathrm{t} 2$ - rezultati drugoga mjerenja (postpartalno)

(1) TABLICA 2

Razlike u pokazateliima subjektivne dobrobiti s obzirom na vrijeme mierenja (prije/poslije dietetova rođenja) i spol roditelia
Iz rezultata prikazanih u Tablici 2 vidi se da je od svih pokazatelja subjektivne dobrobiti bračnih partnera između dvije točke mjerenja došlo do značajne promjene jedino u zadovoljstvu životom. Sudionici koji su između dva mjerenja postali roditelji promijenili su se $\mathrm{u}$ iskazanom stupnju zadovoljstva životom, pri čemu su u drugom mjerenju bili značajno zadovoljniji. Iako većina istraživanja sugerira da neki aspekti kvalitete života i subjektivne dobrobiti opadaju prilikom tranzicije u roditeljstvo (Cast, 2004.; Cowan i Cowan, 1995.; Feeney i sur., 2001.; Fennie, 2001.; Gjerdingen i Center, 2003.; Helms-Erikson, 2001.; Knauth, 2000.), dobiveni rezultati sugeriraju da se stres i zadovoljstvo brakom ne mijenjaju, dok se zadovoljstvo životom značajno povećava - i kod muškaraca i kod žena.

U Tablici 3 donose se korelacije koje su utvrđene između ispitivanih varijabli u oba mjerenja. Promatrajući korelacije 
između zadovoljstva životom, zadovoljstva brakom i zadovoljstva roditeljstvom, uočavaju se značajne povezanosti (od 0,25

(1) TABLICA 3

Matrica korelacija ispitivanih varijabli u dva mierenja do 0,66 ), što govori o postojanju zajedničke podloge ovim trima facetama zadovoljstva pojedinca, odnosno zadovoljstvu kao trajnijoj i stabilnijoj značajki pojedinca.

\begin{tabular}{|c|c|c|c|c|c|c|c|c|c|c|c|c|}
\hline & 2. & 3. & 4. & 5. & 6. & 7. & 8. & 9. & 10. & 11. & 12. & 13. \\
\hline 1. ZŽ1 & $0,54^{* *}$ & $-0,51^{* *}$ & $-0,19$ & $0,66^{* *}$ & $0,30^{*}$ & $0,28^{*}$ & $0,22^{*}$ & $0,57^{* *}$ & $0,60^{* *}$ & $0,38^{* *}$ & $0,32^{* *}$ & $0,49 * *$ \\
\hline 2. ZŽ2 & 1,00 & $-0,31^{* *}$ & $-0,35^{* *}$ & $-0,35^{* *}$ & $0,47^{* *}$ & $0,26^{*}$ & $0,39 * *$ & $0,40^{* *}$ & $0,31^{* *}$ & $0,24^{*}$ & $0,28^{*}$ & $0,35^{* *}$ \\
\hline 3. S1 & & 1,00 & $0,40^{* *}$ & $-0,48^{* *}$ & $-0,33^{* *}$ & $-0,15$ & $-0,22^{*}$ & $-0,35^{* *}$ & $-0,52^{* *}$ & $-0,27^{*}$ & $-0,17$ & $-0,26^{*}$ \\
\hline 4. S2 & & & 1,00 & $-0,14$ & $-0,43^{* *}$ & 0,09 & $-0,20$ & $-0,23^{*}$ & $-0,34^{* *}$ & $-0,04$ & $-0,12$ & $-0,22^{*}$ \\
\hline 5. ZB1 & & & & 1,00 & $0,53^{* *}$ & 0,15 & $0,25^{*}$ & $0,41^{* *}$ & $0,44^{* *}$ & $0,23^{*}$ & $0,25^{*}$ & $0,36^{* *}$ \\
\hline 6. ZB2 & & & & & 1,00 & $-0,07$ & 0,30 ** & $0,30^{* *}$ & $0,30^{* *}$ & 0,12 & 0,06 & $0,23^{*}$ \\
\hline 7. Komp & & & & & & 1,00 & $0,35^{* *}$ & 0,04 & 0,07 & $0,23^{*}$ & 0,04 & $-0,06$ \\
\hline 8. Zad & & & & & & & 1,00 & 0,15 & $0,27^{*}$ & 0,03 & 0,04 & 0,08 \\
\hline 9. E & & & & & & & & 1,00 & $0,49^{* *}$ & 0,06 & $-0,04$ & $0,50^{* *}$ \\
\hline 10. ES & & & & & & & & & 1,00 & 0,18 & 0,05 & $0,27^{*}$ \\
\hline 11. U & & & & & & & & & & 1,00 & $0,35^{* *}$ & $0,34^{* *}$ \\
\hline 12. $\mathrm{S}$ & & & & & & & & & & & 1,00 & $0,48^{* *}$ \\
\hline 13. I & & & & & & & & & & & & 1,00 \\
\hline
\end{tabular}

${ }^{*} \mathrm{p}<0,05 ;{ }^{* *} \mathrm{p}<0,01$

ZŽ - zadovoljstvo životom, ZB - zadovoljstvo brakom; S - stres; Komp - roditeljska kompetentnost; Zad - zadovoljstvo roditeljstvom; E - ekstraverzija; ES - emocionalna stabilnost; U - ugodnost; S - savjesnost; I - intelekt

U istraživanje se krenulo od pretpostavke da će subjektivnoj dobrobiti partnera nakon rođenja djeteta pridonijeti

() TABLICA 4 Rezultati hijerarhijske regresijske analize sa zadovoljstvom životom u drugom mierenju kao kriterijem neke osobine ličnosti, zadovoljstvo partnerskim odnosom prije rođenja djeteta, kao i pozitivan doživljaj roditeljstva. Kako bi se provjerila navedena hipoteza, provedene su hijerarhijske regresijske analize sa zadovoljstvom životom i brakom u drugom mjerenju kao kriterijima.

\begin{tabular}{lcccc}
\hline Prediktori & $\mathrm{R}^{2}$ & $\Delta \mathrm{R}^{2}$ & $\mathrm{~F}(\mathrm{df})$ & $\beta$ \\
\hline $\begin{array}{l}\text { (1. korak) osobine ličnosti } \\
\quad \text { Ekstraverzija }\end{array}$ & 0,27 & & $5,46^{* *}(5,74)$ & \\
$\quad$ Emocionalna stabilnost & & & & $0,36^{*}$ \\
$\quad$ Ugodnost & & & 0,10 \\
$\quad$ Savjesnost & & & & 0,11 \\
$\quad$ Intelekt & 0,37 & $0,10^{* *}$ & $6,18^{* *}(7,72)$ & $0,26^{*}$ \\
$\begin{array}{l}\text { (2. korak) doživljaj roditeljstva } \\
\text { Zadovoljstvo roditeljstvom }\end{array}$ & & & & $0,27^{*}$ \\
$\quad$ Roditeljska kompetentnost & & & 0,13 \\
(3. korak) zadovoljstvo brakom u 2. mjerenju & 0,46 & $0,09^{* *}$ & $7,64^{* *}(8,71)$ & $0,33^{* *}$
\end{tabular}

${ }^{*} \mathrm{p}<0,05 ;{ }^{* *} \mathrm{p}<0,01$

$\mathrm{R}^{2}$ - ukupni doprinos prediktora objašnjenoj varijanci; $\Delta \mathrm{R}^{2}$ - doprinos pojedine skupine prediktora objašnjenoj varijanci; $\beta$ - $\beta$ koeficijent u koraku u kojem je varijabla uvedena 
DRUŠ. ISTRAŽ. ZAGREB GOD. 21 (2012)

BR. $2(116)$

STR. $341-361$

REIĆ ERCEGOVAC, I. PENEZIĆ, Z:

SUBJEKTIVNA..

(1) TABLICA 5

Rezultati hijerarhiijske regresijske analize sa zadovoljstvom brakom u drugom mierenju kao kriterijem
Prema pretpostavci istraživanja, pošlo se od pozitivne osobine ličnosti, misleći kako će i pozitivan doživljaj roditeljstva pridonijeti zadovoljstvu životom nakon djetetova rođenja, što se u ovom slučaju djelomično potvrdilo. Stoga su osobine ličnosti uvedene $\mathrm{u}$ analizu $\mathrm{u}$ prvom koraku i pokazalo se da pridonose objašnjenju varijance zadovoljstva životom (27\%), pri čemu su se ekstraverzija i savjesnost izdvojile kao značajni pojedinačni prediktori (Tablica 4). Uz kontrolu osobina ličnosti, doživljaj roditeljstva također se pokazao prediktivnim za zadovoljstvo životom. Zadovoljstvo brakom očekivano je prediktivno za zadovoljstvo životom i uz kontrolu utjecaja osobina ličnosti i doživljaja roditeljstva, što ne iznenađuje s obzirom na poznatu važnost zadovoljstva brakom za opće životno zadovoljstvo pojedinca.

\begin{tabular}{lcccr}
\hline Prediktori & $\mathrm{R}^{2}$ & $\Delta \mathrm{R}^{2}$ & $\mathrm{~F}(\mathrm{df})$ & \multicolumn{1}{c}{$\beta$} \\
\hline $\begin{array}{l}\text { (1. korak) osobine ličnosti } \\
\text { Ekstraverzija }\end{array}$ & 0,22 & & $3,11^{*}(5,74)$ & 0,19 \\
$\quad$ Emocionalna stabilnost & & & 0,18 \\
$\quad$ Ugodnost & & & $-0,01$ \\
$\quad \begin{array}{l}\text { Savjesnost } \\
\text { Intelekt }\end{array}$ & & & $-0,08$ \\
$\begin{array}{l}\text { (2. korak) doživljaj roditeljstva } \\
\text { Zadovoljstvo roditeljstvom }\end{array}$ & 0,33 & $0,11^{* *}$ & $3,71^{* *}(7,72)$ & 0,19 \\
$\quad$ Roditeljska kompetentnost & & & & $0,37^{* *}$ \\
(3. korak) zadovoljstvo brakom u 1. mjerenju & 0,54 & $0,19^{* *}$ & $7,38^{* *}(8,71)$ & $0,61^{* *}$ \\
\hline
\end{tabular}

${ }^{*} \mathrm{p}<0,05 ;{ }^{* *} \mathrm{p}<0,01$

$\mathrm{R}^{2}$ - ukupni doprinos prediktora objašnjenoj varijanci; $\Delta \mathrm{R}^{2}$ - doprinos pojedine skupine prediktora objašnjenoj varijanci; $\beta$ - $\beta$ koeficijent $\mathrm{u}$ koraku u kojem je varijabla uvedena

U prvom koraku analize uvedene su osobine ličnosti koje objašnjavaju $22 \%$ varijance kriterija, no ni jedna osobina nije se pokazala značajnim prediktorom zadovoljstva brakom $\mathrm{u}$ posljednjem koraku analize. Kao značajni prediktori zadovoljstva brakom izdvojili su se zadovoljstvo roditeljstvom te zadovoljstvo brakom tijekom trudnoće.

Ovo upućuje na stabilnost zadovoljstva brakom tijekom vremena, a tome u prilog ide i činjenica da nisu utvrđene razlike u zadovoljstvu brakom bračnih partnera između dva mjerenja (Tablica 2), kao i korelacije između dvije točke mjerenja (Tablica 1). Ovim rezultatom samo je djelomično potvrđena pretpostavka o doprinosu raznih osobnih i odnosnih varijabli prilikom tranzicije u roditeljstvo zadovoljstvu brakom roditelja nakon djetetova rođenja. Naime, pretpostavljalo se da će važniju ulogu u subjektivnoj dobrobiti roditelja imati neke osobine ličnosti (savjesnost, ugodnost, otvorenost novim iskustvima), 
kao i pozitivan doživljaj roditeljstva, odnosno visoko zadovoljstvo roditeljstvom te visoka razina roditeljske kompetentnosti.

RASPRAVA
Ispitujući promjene koje su se dogodile bračnim partnerima prilikom tranzicije u roditeljstvo, pokazalo se da između trudnoće i devet mjeseci nakon porođaja nema značajnih promjena u razini stresa i zadovoljstvu brakom, dok je utvrđen porast u zadovoljstvu životom i kod žena i kod muškaraca. Neka su istraživanja pokazala da očevi iskazuju veće opadanje zadovoljstva od njihovih bračnih partnerica (Wadsby i Sydsjo, 2001.; Willen, 1996.), dok neka druga istraživanja sugeriraju da se tranzicija $u$ roditeljstvo negativno odražava prije svega na majke (Belsky i Pensky, 1988.), jer je kod njih izraženiji manjak vremena za posvećivanje sebi i slobodnim aktivnostima, kao i umor, manjak sna te stres. Podaci o mentalnom zdravlju majki u postpartalnom razdoblju pokazuju da je ono ugroženije $\mathrm{u}$ odnosu na mentalno zdravlje očeva (Olsen, 2006.). U ovom istraživanju čini se da tranzicija ne utječe negativno na dobrobit roditelja, a općenito se može reći da se muškarci i žene po tome ne razlikuju.

Moguće je da je roditeljstvo snažna emocionalna dobit za roditelje, povećavajući osjećaj osobnoga dostignuća te omogućujući zadovoljenje niza psiholoških potreba (Feeney i sur., 2001.), što ima pozitivne efekte na zadovoljstvo životom. Dobivena razlika u zadovoljstvu životom između dva mjerenja može se dijelom pripisati i generativnom djelovanju. Naime, istraživanja pokazuju kako je generativna briga, kao jedna od sastavnica generativnosti prema modelu McAdamsa i de St. Aubina (1992.), značajno pozitivno povezana sa psihološkom dobrobiti, i to sa zadovoljstvom životom i ukupnom srećom (de St. Aubin i McAdams, 1995.; Tucak, 2005.). Nadalje, generativnost utječe na samoprocjenu pojedinca, odnosno na način kako odrasli ljudi evaluiraju svoj život (Keyes i Ryff, 1998.), što zapravo znači da generativnost ima pozitivne efekte na zadovoljstvo životom. Generativnost se može realizirati na razne načine, no budući da je najbolje predstavljena upravo u kontekstu roditeljstva (Demick, 2002.), opravdanim se čini zaključiti da je generativno djelovanje dijelom dovelo do povećanja zadovoljstva životom bračnih partnera u ovom istraživanju.

Pri objašnjenju dobivenih rezultata treba razmotriti još nekoliko činjenica. Prvo, vremensko određenje perioda koji se $\mathrm{u}$ literaturi naziva tranzicija $\mathrm{u}$ roditeljstvo nije jednoznačno definirano. Naime, u nekim je istraživanjima zahvaćen period od sklapanja braka pa sve do nekoliko godina nakon djetetova rođenja, dok je u nekim istraživanjima zahvaćen kraći 
DRUŠ. ISTRAŽ. ZAGREB GOD. 21 (2012)

BR. 2 (116),

STR. 341-361

REIĆ ERCEGOVAC, I. PENEZIĆ, Z:

SUBJEKTIVNA.. period, od trudnoće do nekoliko tjedana postpartalno. Nije opravdano očekivati slične rezultate ako se efekti tranzicije $u$ roditeljstvo utvrđuju nekoliko dana ili tjedana postpartalno ili ako je ispitivanje provedeno kada dijete ima šest mjeseci ili godinu dana. Osim toga, čini se važnim navesti i dvojbu oko definiranja tranzicije u roditeljstvo - sigurno je da ona obuhvaća promjenu na mnogo razina i zahtijeva reorganiziranje dotadašnjega života, pa je pod utjecajem očekivanja, vještina i znanja, okoline te emocionalne i fizičke dobrobiti roditelja. Iz toga se vidi da je tranzicija u roditeljstvo određena prije svega psihološkim promjenama unutarnjega svijeta roditelja te $u$ organizaciji njegovih uloga i odnosa, pa ju je stoga nemoguće strogo vremenski odrediti.

Nadalje, $\mathrm{u}$ dijelu istraživanja tranzicije $\mathrm{u}$ roditeljstvo rabljen je transverzalni nacrt, pa je pitanje jesu li promjene koje su uočene u subjektivnoj dobrobiti partnera zaista efekt tranzicije ili su se skupine ispitanika razlikovale u subjektivnoj dobrobiti i bez obzira na roditeljstvo. I konačno, $\mathrm{u}$ istraživanjima subjektivne dobrobiti prilikom tranzicije $\mathrm{u}$ roditeljstvo primijenjen je niz mjera, a pojedini vidovi subjektivne dobrobiti mjereni su na različite načine, pa i u tome treba tražiti razloge dobivanja različitih zaključaka o subjektivnoj dobrobiti partnera prilikom tranzicije u roditeljstvo. Pri pokušaju tumačenja rezultata dobivenih ovim istraživanjem nametnula se još jedna mogućnost. Naime, neki autori navode da je tradicionalna raspodjela bračnih uloga prediktor uspješne tranzicije u roditeljstvo (Ward, 2004.) te da čak i u brakovima s ravnopravnom raspodjelom obveza nakon rođenja djeteta dolazi do pomaka prema tradicionalnoj raspodjeli uloga (Kalicki i sur., 1998.; Lemme, 1995.). Uzimajući u obzir da je naše društvo po socijalnoj strukturi tradicionalna i konzervativna sredina, moguće je da rođenje djeteta ne narušava bračno zadovoljstvo kao ni ostale oblike dobrobiti roditelja. Ipak je, uz neke iznimke, većina stranih istraživanja o ovoj tematici iz skandinavskoga, sjevernoameričkog i zapadnoeuropskog područja, društava i kultura koji njeguju drugačiju tradiciju i gdje se roditeljstvo sve više shvaća kao osobno žrtvovanje nauštrb individualizma i osobnih sloboda pojedinaca (Alwin, 1996.) te gdje su mladi ljudi manje spremni na kompromise i odricanja, nužna za realiziranje vlastite roditeljske uloge, stavljajući hedonističke potrebe kao prioritetne. Valja pretpostaviti da će vjerojatnije u takvim društvima tranzicija u roditeljstvo negativnije utjecati na subjektivnu dobrobit pojedinaca nego u društvima $s$ tradicionalnim sustavom vrijednosti bračnih partnera u kojem su djeca na vrlo visokom mjestu u određenju životnoga smisla. Upravo u kontekstu prevladavajućega tradicionalnog sustava bračnih i obiteljskih vrijednosti, gdje je roditeljstvo gotovo najvažnije u definiranju nečijeg identiteta, logično je da dolazak djeteta u obitelj nema negativne efekte 
DRUŠ. ISTRAŽ. ZAGREB GOD. 21 (2012), BR. $2(116)$

STR. $341-361$

REIĆ ERCEGOVAC, I., PENEZIĆ, Z.:

SUBJEKTIVNA.. na dobrobit roditelja. Ili ih, upravo u skladu s dominantnom tradicionalnom orijentacijom i sustavom vrijednosti, roditelji nisu spremni priznati. Moguće je da bi osvještavanje ili prepoznavanje negativnih utjecaja roditeljstva na njihovu osobnu dobrobit zapravo značilo da su manje vrijedni i dobri kao roditelji, što bi pak osjetno narušilo njihovu sliku o sebi.

Povećanje zadovoljstva životom može se promatrati i u kontekstu suvremene revidirane verzije Maslowljeve piramide ljudskih potreba (Kenrick i sur., 2010.), po kojoj je na vrhu piramide ljudskih potreba upravo roditeljstvo. Budući da je po teoriji samoodređenja osobna dobrobit izravna funkcija zadovoljavanja psiholoških potreba, odnosno da zadovoljenje tih potreba vodi psihološkom rastu, integritetu i psihološkoj dobrobiti, ne začuđuje što je zadovoljenje potrebe za roditeljstvom, kao vrhunske ljudske potrebe (Kenrick i sur., 2010.), dovelo do povećanoga zadovoljstva životom.

Iz Tablice 5 vidi se da je najznačajniji prediktor zadovoljstva brakom $\mathrm{u}$ drugom mjerenju zadovoljstvo brakom tijekom trudnoće, što je u skladu s rezultatima nekih ranijih istraživanja (Cowan i sur., 1994.; Knauth, 2000.; Wallace i Gottlib, 1990.). U kontekstu uspješne prilagodbe na roditeljstvo, ranija su istraživanja upozorila upravo na veliku važnost kvalitete bračnog odnosa prije djetetova rođenja, koja se pokazala prediktivnom za postpartalni stres i postpartalno zadovoljstvo brakom (Morse i sur., 2000.; Matthey i sur., 2003.; Cox i sur., 1999.). Zadovoljstvo roditeljstvom također se izdvojilo kao značajan prediktor zadovoljstva brakom, što je u skladu s dosadašnjim istraživanjima povezanosti bračnoga i roditeljskoga funkcioniranja. Naime, u nizu ranijih istraživanja pokušalo se istražiti kakav je odnos zadovoljstva roditeljstvom i roditeljske kompetentnosti s pokazateljima bračne kvalitete i bračnih procesa. Neki su autori utvrdili da je roditeljska kompetentnost povezana s kvalitetom bračnih odnosa, odnosno s bračnom kohezijom, ali samo kod očeva (Wandersman i sur., 1980.). Ohan i sur. (2000.) u tom su kontekstu ispitivali dva aspekta bračnih odnosa - zadovoljstvo brakom i roditeljsku usklađenost oko roditeljskoga stila. Autori su utvrdili da su oba aspekta bračnih odnosa povezana sa zadovoljstvom roditeljstvom te navode da se roditelji koji doživljavaju više zadovoljstva u bračnom odnosu i slažu se oko odgoja djeteta ujedno međusobno više podupiru s obzirom na roditeljsko ulaganje i trud. To onda vjerojatno pruža osnovu za izražavanje veće razine zadovoljstva roditeljstvom. $\mathrm{U}$ tom istraživanju nije utvrđena veza između mjerenih aspekata bračnih odnosa i roditeljske kompetentnosti, pa autori zaključuju da je samo afektivna komponenta doživljaja roditeljstva povezana s bračnim procesima unutar obitelji. Povezanost bračnoga zadovoljstva i zadovoljstva roditeljstvom može se objasniti i time da roditelji koji doživljavaju veće zadovolj- 
DRUŠ. ISTRAŽ. ZAGREB GOD. 21 (2012)

BR. $2(116)$

STR. 341-361

REIĆ ERCEGOVAC, I. PENEZIĆ, Z:

SUBJEKTIVNA.. stvo u svojem partnerskom odnosu mogu bolje funkcionirati $\mathrm{u}$ roditeljskoj ulozi, jer skladan partnerski odnos podrazumijeva i bolje slaganje oko roditeljskih pitanja, odgojnih utjecaja i odnosa na relaciji roditelj - dijete (Ohan, 2000.). Stoga ne treba čuditi ova značajna korelacija. Moguće je da roditelji koji su zadovoljni u svojoj roditeljskoj ulozi prenose na određeni način to zadovoljstvo i u druge domene života, pa tako i bračnu. Ako se uzme u obzir teorija obitelji kao sustava koji se sastoji od niza podsustava koji su u stalnoj međusobnoj interakciji, onda je logično da funkcioniranje jednoga podsustava, npr. roditelj - dijete, utječe na funkcioniranje podsustava bračnih partnera. Stoga je opravdano zaključiti da su zadovoljstvo brakom i roditeljstvom povezani tako da zadovoljstvo brakom može moderirati zadovoljstvo roditeljstvom, ali i obrnuto.

Neka od ograničenja ovog istraživanja odnose se na relativno malen broj longitudinalno praćenih parova, kao i na odabir nekih mjera primijenjenih $\mathrm{u}$ istraživanju. To se prije svega odnosi na zadovoljstvo brakom, jer je kao pokazatelj bračne kvalitete upotrijebljena varijabla zadovoljstva brakom mjerena jednodimenzionalnom skalom kojom je procijenjeno ukupno zadovoljstvo brakom. Čini se potrebnim u idućim istraživanjima zahvatiti i druge dimenzije bračnoga funkcioniranja, kako bi se detaljnije ispitalo i razjasnilo koji se to oblici bračnog odnosa mijenjaju prilikom tranzicije $u$ roditeljstvo i u kojem smjeru.

Govoreći o ograničenjima istraživanja, valja spomenuti i da su sudionici u ovom istraživanju donekle selekcionirana skupina u odnosu na populaciju budućih roditelja, samim time što su uglavnom kontaktirani zahvaljujući tome što su sudjelovali u radionicama i edukacijama za buduće roditelje. To, naime, samo po sebi može podrazumijevati da je oboje roditelja uključeno u dolazak djeteta već od prenatalnog razdoblja.

Rezultati ovog istraživanja, unatoč svojim ograničenjima, mogu ponuditi neke nove spoznaje i dati smjernice za buduća istraživanja, to više što su na nacionalnom uzorku slična istraživanja vrlo rijetka. S metodološke strane, upravo se najprihvatljivijim čini ispitivati tranziciju $u$ roditeljstvo, i to tako da se isti sudionici prate kroz dulje razdoblje.

Ahlborg, T. (2004.), Experienced Quality of the Intimate Relationship in First-Time Parents. Qualitative and Quantitative Studies, Doctoral dissertation of public health. Sweden, Göteborg, Nordic School of Public Health, http://www.toneahlborg.se/Dr-of-PH.pdf/

Alwin, D. F. (1996.), From Childbearing to Childrearing: The Link between Declines in Fertility and Changes in the Socialization of Children. U: J. B. Casterline, R. D. Lee i K. Foote (ur.), Fertilitiy in the United States: New Patterns, New Theories. Population and Development Review, A Supplement to Volume 22. New York, The Population Council. 
DRUŠ. ISTRAŽ. ZAGREB GOD. 21 (2012), BR. 2 (116)

STR. $341-361$

REIĆ ERCEGOVAC, I., PENEZIĆ, Z:: SUBJEKTIVNA.
Barrett, G., Pendry, E., Peacock, J., Victor, C., Thakar, R. i Manyonda, I. (2000.), Womens' Sexual Health after Childbirth. British Journal of Obstetrics and Gynaecology, 107 (2): 186-195. doi:10.1111/j.1471-0528.2000. tb11689.x

Belsky, J. i Pensky, E. (1988.), Marital Change across the Transition to Parenthood. Marriage and Family Review, 12 (3-4): 133-156. doi:10.1300/ J002v12n03_08

Bronfenbrenner, U. (1979.), The Ecology of Human Development: Experiments by Nature and Design, Cambridge, MA, Harvard University Press.

Cast, A. D. (2004.), Well-Being and the Transition to Parenthood: An Identity Theory Approach. Sociological Perspectives, 47 (1): 55-78. doi:10. 1525/sop.2004.47.1.55

Cowan, C. P. i Cowan, P. A. (2000.), When Partners Become Parents: The Big Life Change for Couples, New York, Basic Books.

Cowan, C. P. i Cowan, P. A. (1995.), Interventions to Ease the Transition to Parenthood: Why They are Needed and What they Can Do. Family Relations, 44 (4): 412-423. doi:10.2307/584997

Cowan, P. A., Cowan, C. P., Schulz, M. i Heming, G. (1994.), Prebirth to Preschool Family Factors Predicting Children's Adaptation to Kindergarten. U: R. D. Parkes i S. G. Kellam (ur.), Exploring Family Relationships with Other Social Contexts (str. 75-114), Hillsdale, New Jersey, Erlbaum.

Cox, M. J., Paley, B., Burchinal, M. i Payne, C. C. (1999.), Marital Perceptions and Interactions across the Transition to Parenthood. Journal of Marriage and the Family, 61 (3): 611-625. doi:10.2307/353564

De Judicibus, M. A. i McCabe, M. P. (2002.), Psychological Factors and the Sexuality of Pregnant and Postpartum Women. Journal of Sex Research, 39 (2): 94-103. doi:10.1080/00224490209552128

De St. Aubin, E. i McAdams, D. P. (1995.), The Relations of Generative Concern and Generative Action to Personality Traits, Satisfaction/ Happiness with Life and Ego Development. Journal of Adult Development, 2 (2): 99-112. doi:10.1007/BF02251258

DeFrain, J. i Olson, D. H. (1999.), Contemporary Family Patterns and Relationships. U: M. B. Sussman, S. K. Steinmetz i G. W. Peterson (ur.), Handbook of Marriage and the Family (str. 309-326), New York, Plenum Press.

Demick, J. (2002.), Stages of Parental Development. U: M. H. Bornstein (ur.), Handbook of Parenting: Vol. 3: Being and Becoming a Parent (str. 389-415), Mahwah, New Jersey, Lawrence Erlbaum Associates.

DeNeve, K. M. i Cooper, H. (1998.), The Happy Personality: A Meta-Analysis of 137 Personality Traits and Subjective Well-Being. Psychological Bulletin, 124 (2): 197-229. doi:10.1037//0033-2909.124.2.197

Diener, E., Scollon, C. N., Lucas, R. E. (2004.), The Evolving Concept of Subjective Well-Being: The Multifaceted Nature of Happiness, Advances in Cell Aging and Gerontology, 15: 187-219.

Diener, E., Lucas, R. E. i Scollon, C. N. (2006.), Beyond the Hedonic Treadmill: Revising the Adaptation Theory of Well-Being. American Psychologist, 61 (4): 305-314. doi:10.1037/0003-066X.61.4.305 
DRUŠ. ISTRAŽ. ZAGREB GOD. 21 (2012) BR. 2 (116),

STR. 341-361

REIĆ ERCEGOVAC, I. PENEZIĆ, Z: SUBJEKTIVNA..
Di Tella, R., MacCulloch, R. J. i Oswald, A. J. (2003.), The Macroeconomics of Happiness. The Review of Economics and Statistics, 85 (4): 809-827. doi:10.1162/003465303772815745

Doss, B. D., Rhoades, G. K., Stanley, S. M. i Markman, H. J. (2009.), The Effect of the Transition to Parenthood on Relationship Quality: An 8-Year Prospective Study. Journal of Personality and Social Psychology, 96 (3): 601-619. doi:10.1037/a0013969

Državni zavod za statistiku RH (2009.), Statističke informacije 2009, Zagreb, Državni zavod za statistiku Republike Hrvatske.

Elek, S. M., Hudson, D. B. i Boufford, C. (2003.), Marital and Parenting Satisfaction and Infant Care Self-Efficacy during the Transition to Parenthood: The Effect of Infant Sex. Issues in Comprehensive Pediatric Nursing, 26 (1): 45-57. doi:10.1080/01460860390183065

Feeney, J. A., Hohaus, L., Noller, P. i Alexander, R. P. (2001.), Becoming Parents. Exploring the Bonds between Mothers, Fathers, and Their Infants. UK, Cambridge University Press.

Fennie, K. M. (2001.), Transition to Parenthood from Coupledhood. Implications for Therapy. University of Wisconsin: Research paper for the Master of Science Degree, http://www.uwstout.edu/lib/thesis.

Gibaud-Wallston, J. i Wandersman, L. P. (1978.), Development and Utility of the Parenting Sense of Competence Scale. Proceedings of the 86th Annual Convention of the American Psychological Association, August-September 1978. Toronto, Canada. Washington, DC, American Psychological Association.

Gjerdingen, D. K. i Center, B. A. (2003.), First-Time Parents' Prenatal to Postpartum Changes in Health, and the Relation of Postpartum Health to Work and Partner Characteristics. The Journal of the American Board of Family Medicine, 16 (4): 304-311. doi:10.3122/jabfm. 16.4.304

Goldberg, L. R. (2001.), International Personality Item Pool: A Scientific Collaboratory for the Development of Advanced Measures of Personality Traits and Other Individual Differences, http://ipip.ori.org/ipip.

Helms-Erikson, H. (2001.), Marital Quality Ten Years after the Transition to Parenthood: Implications of the Timing of Parenthood and the Division of Housework. Journal of Marriage and the Family, 63 (4): 1099-1110. doi:10.1111/j.1741-3737.2001.01099.x

Hills, P. i Argyle, M. (2001.), Emotional Stability as a Major Dimension of Happiness. Personality and Individual Differences, 31 (8): 1357-1364. doi:10.1016/S0191-8869(00)00229-4

Johnston, C. i Mash, E. J. (1989.), A Measures of Parenting Satisfaction and Efficacy. Journal of Clinical Child Psychology, 18 (2): 167-175. doi:10. 1207/s15374424jccp1802_8

Kalicki, B., Fthenakis, W. E., Peitz, G. i Engfer, A. (1998.), Gender Roles at the Transition to Parenthood. Poster presented at the XVth Biennial ISSBD Meeting Berne.

Kenrick, D. T., Griskevicius, V., Neuberg, S. L. i Schaller, M. (2010.), Renovating the Pyramid of Needs: Contemporary Extensions Built Upon Ancient Foundations. Perspectives on Psychological Science, 5 (3): 292-314. doi:10.1177/1745691610369469 
DRUŠ. ISTRAŽ. ZAGREB GOD. 21 (2012), BR. 2 (116)

STR. $341-361$

REIĆ ERCEGOVAC, I., PENEZIĆ, Z:: SUBJEKTIVNA..
Keyes, C. L. M. i Ryff, C. D. (1998.), Generativity in Adult Lives: So cial Structural Contours and Quality of Life Consequences. U: D. P. McAdams i E. de St. Aubin (ur.), Generativity and Adult Development: Psychosocial Perspectives on Caring for and Contributing to the Next Generation (str. 227-263), Washington, DC, American Psychological Association. Knauth, D. (2000.), Predictors of Parental Sense of Competence for the Couple during the Transition to Parenthood. Research in Nursing $\mathcal{E}$ Health, 23 (6): 496-509. doi:10.1002/1098-240X(200012)23:6<496::AIDNUR8>3.0.CO;2-1

Lacković-Grgin, K. (1994.), Samopoimanje mladih, Jastrebarsko, Naklada Slap.

Lawrence, E., Rothman, A. D., Cobb, R. J., Rothman, M. T. i Bradbury, T. N. (2008.), Marital Satisfaction across the Transition to Parenthood. Journal of Family Psychology, 22 (1): 41-50. doi:10.1037/08933200.22.1.41

Lemme, B. H. (1995.), Development in Adulthood, Boston, Allyn and Bacon. Lovibond, S. H. i Lovibond, P. F. (1995.), Manual for the Depression Anxiety Stress Scales (DASS), Sydney, Australia, Psychology Foundation of Australia.

Ljubetić, M. (2007.), Biti kompetentan roditelj, Zagreb, Mali profesor. Matthey, S., Barnett, B., Howie, P. i Kavanagh, K. J. (2003.), Diagnosing Postpartum Depression in Mothers and Fathers: Whatever Happened to Anxiety? Journal of Affective Disorders, 74 (2): 139-147. doi:10.1016/S0165-0327(02)00012-5

McAdamas, D. P. i de St. Aubin, E. (1992.), A Theory of Generativity and Its Assessment through Self-Report, Behavioral Acts and Narrative Themes in Autobiography. Journal of Personality and Social Psychology, 62: 1003-1015.

McConachie, H., Hammal, D., Welsh, B., Keane, B., Waterston, T., Parker, L. i Cook, M. (2008.), Wellbeing of New Mothers. Journal of Community Practice, 81 (3): 19-22.

Medina, A. M., Lederhos, C. L. i Lillis, T. A. (2009.), Sleep Disruption and Decline in Marital Satisfaction across the Transition to Parenthood. Family, Systems and Health, 27 (2): 153-160. doi:10.1037/a0015762

Morse, C. A., Buist, A. i Durkin, S. (2000.), First-Time Parenthood: Influences on Pre- and Postnatal Adjustment in Fathers and Mothers. Journal of Psychosomatic Obstetrics and Gynecology, 21 (2): 109-120. doi:10.3109/01674820009075616

Obradović, J. i Čudina-Obradović, M. (2001.), Number of Children in the Family as a Predictor of Parents' Life Satisfaction. Društvena istraživanja, 10 (4-5): 685-707.

Ohan, J. L., Leung, D. W. i Johnston, C. (2000.), The Parenting Sense of Competence Scale: Evidence of Stable Factor Structure and Validity. Canadian Journal of Behavioral Science, 32 (4): 251-261. doi:10.1037/ h0087122

Ohrling, K. i Nystrom, K. (2004.), Parenthood Experiences during the Child's First Year: Literature Review. Journal of Advanced Nursing, 46 (3): 319-330. doi:10.1111/j.1365-2648.2004.02991.x 
DRUŠ. ISTRAŽ. ZAGREB GOD. 21 (2012) BR. 2 (116),

STR. 341-361

REIĆ ERCEGOVAC, I. PENEZIĆ, Z: SUBJEKTIVNA..
Olsen, T. M., Laursen, T. M., Pedersen, C. B., Mors, O. i Martensen, P. B. (2006.), New Parents and Mental Disorders. Journal of the American Medical Association, 296 (21): 2582-2589.

Pavot, W. U., Diener, E. i Fujita, F. (1990.), Extraversion and Happiness. Personality and Individual Differences, 11 (12): 1299-1306. doi:10. 1016/0191-8869(90)90157-M

Penezić, Z. (1996.), Zadovoljstvo životom - provjera konstrukta, Neobjavljeni diplomski rad, Filozofski fakultet u Zadru.

Pollock, M. A., Amankwaa, L. C. i Amankwaa, A. A. (2005.), First-Time Fathers and Stressors in the Postpartum Period. The Journal of Perinatal Education, 14 (2): 19-25. doi:10.1624/105812405X44682

Roach, A. J., Frazier, L. P. i Bowden, S. R. (1981.), The Marital Satisfaction Scale: Development of a Measure for Intervention Research. Journal of Marriage and the Family, 43 (3): 537-546. doi:10.2307/351755

Ross, L. E. i McLean, L. M. (2006.), Anxiety Disorders During Pregnancy and the Postpartum Period: A Systematic Review. Journal of Clinical Psychiatry, 67 (8): 1285-1298. doi:10.4088/JCP.v67n0818

Sabatelli, R. M. i Waldron, R. J. (1995.), Measurement Issues in the Assessment of the Experience of Parenthood. Journal of Marriage and the Family, 57 (4): 969-980. doi:10.2307/353416

Schoon, I., Hansson, L. i Salmela-Aro, K. (2005.), Combining Work and Family Life: Life Satisfaction among Married and Divorced Man and Women in Estonia, Finland and the UK. European Psychologist, 10 (4): 309-319. doi:10.1027/1016-9040.10.4.309

Tucak, I. (2005.), Generativna briga u tri perioda odrasle dobi: relacija s nekim sociodemografskim varijablama, životnim zadovoljstvom i percepcijom osobne (ne)kompetentnosti. Suvremena psihologija, 8 (2): 179-195.

Veenhoven, R. (1995.), Average Level of Satisfaction in 10 European Countries: Explanation of Differences. U: W. E. Saris, R. Veenhoven, A. C. Scherpenzeel i B. Bunting (ur.), A Comparative Study of Satisfaction with Life in Europe (str. 243-252), Budapest, Eötvös University Press.

Von Sydow, K. (1999.), Sexuality during Pregnancy and After Childbirth. A Metacontent Analysis of 59 Studies. Journal of Psychosomatic Research, 47 (1): 27-49. doi:10.1016/S0022-3999(98)00106-8

Wadsby, G. i Sydsjo, G. (2001.), From Pregnancy to Parenthood. Nordisk Psykologi, 53: 275-288.

Wallace, P. M. i Gotlib, I. H. (1990.), Marital Adjustment during the Transition to Parenthood: Stability and Predictors of Change. Journal of Marriage and Family, 52 (1): 21-29. doi:10.2307/352834

Wandersman, L., Wandersman, A. i Kahn, S. (1980.), Social Support in the Transition to Parenthood. Journal of Community Psychology, 8 (4): 332-342. doi:10.1002/1520-6629(198010)8:4<332::AID-JCOP22900 80407>3.0.CO;2-H

Ward, J. P. (2004.), Identifying Factors Associated with Successful Transition to Parenthood, Doctoral Dissertation, US, Indiana, Purdue University. 
DRUŠ. ISTRAŽ. ZAGREB GOD. 21 (2012),

BR. $2(116)$

STR. $341-361$

REIĆ ERCEGOVAC, I. PENEZIĆ, Z.:

SUBJEKTIVNA.
Wilkinson, R. B. (1995.), Changes in Psychological Health and the Marital Relationship Through Childbearing - Transition or Process as Stressor. Australian Journal of Psychology, 47 (2): 86-92. doi:10.1080/ 00049539508257505

Willen, H. (1996.), The Impact of Wish for Children and Having Children on Attainment and Importance of Life Values. Journal of Comparative Family Studies, 27: 499-518.

\section{Subjective Well-Being of Spouses during the Transition to Parenthood}

Ina REIĆ ERCEGOVAC

Faculty of Philosophy, Split

Zviezdan PENEZIĆ

University of Zadar, Zadar

Parenting is one of the most important experiences of individuals which brings changes in all aspects of life. The transition to parenthood is one of the most universal transitions, and most researchers and practitioners in the field of parenting and intimate relationships agrees that the transition to parenthood is reflected in the overall functioning of an individual who becomes a parent. The aim of this study was to determine if there are changes in subjective well-being of spouses during the transition to parenthood, and what the role of positive personality traits, satisfaction with marriage during the pregnancy, parenting satisfaction and parental competence in contribution to subjective well-being of new parents is. The study included 40 couples $(\mathrm{N}=80)$ that were examined at two time points during the second trimester of pregnancy, and approx. nine months postpartum. The following instruments were used: $A$ questionnaire of general information, General life satisfaction scale, The scale of satisfaction with marriage, Stress scale, Scale of parental competence and Personality traits questionnaire. The results showed that the baby does not violate marriage satisfaction, but contributes to the increase in life satisfaction of spouses, which is discussed in the context of the psychological welfare of parenting, generativity and the revised hierarchy of human needs. Personality traits, especially extraversion and conscientiousness, contribute to life satisfaction during the transition to parenthood. Satisfaction with marriage during the pregnancy and parenting satisfaction, as an affective component of parenting experience, were the best predictors of satisfaction with marriage nine months postpartum.

Keywords: transition to parenthood, life satisfaction, satisfaction with marriage, parental competence, personality traits 
DRUŠ. ISTRAŽ. ZAGREB

GOD. 21 (2012),

BR. 2 (116),

REIĆ ERCEGOVAC, I.,

PENEZIĆ, Z:

SUBJEKTIVNA. 